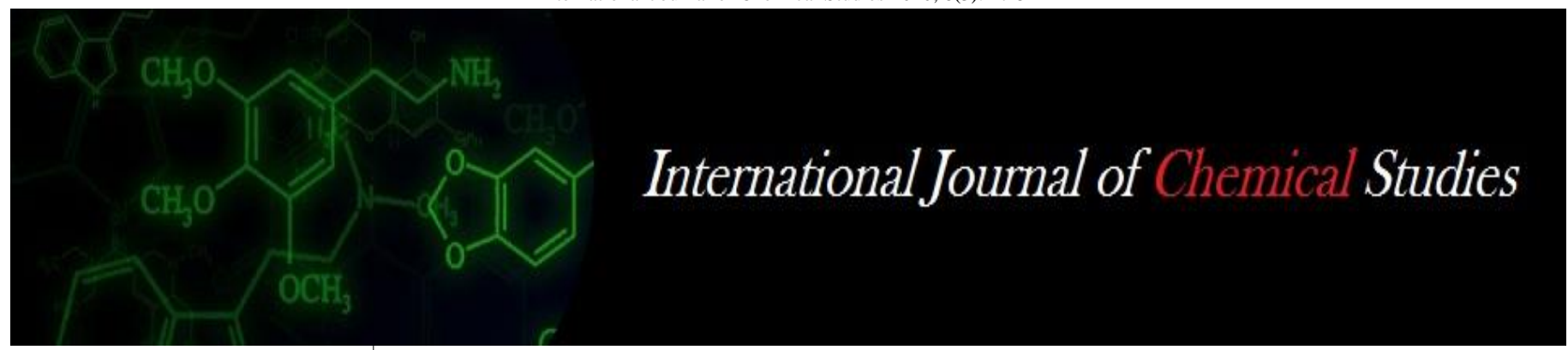

P-ISSN: 2349-8528

E-ISSN: 2321-4902

www.chemijournal.com

IJCS 2020; 8(3): 47-52

(C) 2020 IJCS

Received: 21-03-2020

Accepted: 24-04-2020

Anju Mohan

Department of Soil Science \&

Agricultural Chemistry, TNAU,

Coimbatore, Tamil Nadu, India

\section{P Malarvizhi}

Department of Soil Science \&

Agricultural Chemistry, TNAU,

Coimbatore, Tamil Nadu, India

\section{RK Kaleeswari}

Department of Soil Science \&

Agricultural Chemistry, TNAU,

Coimbatore, Tamil Nadu, India

\section{T Saraswathi}

Department of vegetable crops,

TNAU, Coimbatore, Tamil Nadu, India
Corresponding Author: Anju Mohan

Department of Soil Science \&

Agricultural Chemistry, TNAU,

Coimbatore, Tamil Nadu, India

\section{Effect of organic acid coated phosphatic fertilizer on soil P status, yield and quality of Brinjal}

\author{
Anju Mohan, P Malarvizhi, RK Kaleeswari and T Saraswathi
}

DOI: https://doi.org/10.22271/chemi.2020.v8.i3a.9464

\begin{abstract}
A field experiment was conducted during Rabi, 2019 which is laid out in Randomized Block Design (RBD) with ten treatments and three replications. The treatments comprised of $\mathrm{T}_{1} \mathrm{NK}+\mathrm{P}$ as uncoated DAP, $\mathrm{T}_{2}: \mathrm{NK}+\mathrm{P}$ as FA coated DAP $(5 \%), \mathrm{T}_{3}: \mathrm{NK}+\mathrm{P}$ as FA coated DAP $(10 \%), \mathrm{T}_{4}: \mathrm{NK}+\mathrm{P}$ as FA coated DAP (15\%), T5: NK + P as FA coated DAP (20\%), $\mathrm{T}_{6} \mathrm{NK}+\mathrm{P}$ as HA coated DAP $(5 \%), \mathrm{T}_{7}: \mathrm{NK}+$ $\mathrm{P}$ as HA coated DAP (10\%), $\mathrm{T}_{8}: \mathrm{NK}+\mathrm{P}$ as HA coated DAP $(15 \%), \mathrm{T}_{9}: \mathrm{NK}+\mathrm{P}$ as HA coated DAP (20\%), T 10 : Control. Urea and MOP were used as the source of Nitrogen and potassium respectively. The results from the field experiment revealed that the available $\mathrm{P}$ in the soil, the yield of Brinjal $(\mathrm{CO} 2)$ and the economic returns are varying according to the change in coating concentration and type of organic acids,. There is no significant difference in anthocyanin content and Titrable acidity of Brinjal fruits but slight improvement is found in ascorbic acid content. Significantly higher yield was obtained in $\mathrm{T}_{9}[\mathrm{NK}+$ $\mathrm{P}$ as HA coated DAP (20\%)] and lowest yield was recorded for $\mathrm{T}_{10}, \mathrm{~T}_{6}$ and $\mathrm{T}_{1}$. Humic acid coated treatments found better in yield and available soil $\mathrm{P}$ status compared to Fulvic acid coated treatments.
\end{abstract}

Keywords: Humic acid, Fulvic acid, Brinjal, Di Ammonium Phosphate, Soil available phosphorus, yield

\section{Introduction}

Phosphorus is the main element required for the plant's growth. $\mathrm{P}$ is important for root growth and act as an energy source. DAP is the most widespread phosphate fertilizer because of its high analysis and good physical properties. Phosphorus commonly limits plant growth in deficient condition. The main reason for this deficiency is rapid dissolution and fixation of nutrients in the soil. For reducing P losses and to improve phosphorus use efficiency (PUE), gradual release of $\mathrm{P}$ is essential. Gradual release can be promoted by coating $\mathrm{P}$ fertilizer. Coating with organic or inorganic polymers is most common. To prevent the accumulation of undesirable synthetic residues in the soil that occurs due to inorganic polymer coating, organic polymers act as a promising coating material since they are easily degradable and non-toxic to the environment.

Humic acids (HA) and Fulvic acids (FA) are natural biostimulants and which will improve the growth of plants. The coating of fertilizers using organic acids will help in improving the fertilizer efficiency and also it will reduce the fertilizer losses. Paramasivan et al. (2015) [20] who studied the effect of Humic acid on yield, profitability and nutrient uptake in Brinjal reported that the Humic acid application has increased the yield, profitability and nutrient uptake in Brinjal. Ugur et al. (2013) ${ }^{[25]}$ reported that Humic acid application was found to be effective on yield. Karakurt et al. (2009) ${ }^{[14]}$ studied that increasing soil and foliar HA concentrations resulted in a significant enhancement in mean fruit weight of pepper. Similarly Humic acids acts as a soil conditioner and improves the ability of soil to hold more nutrients which are available to plant (Iqbal and Mastorakis, 2014) ${ }^{[13]}$. Foliar application of Fulvic acid at different levels on plant growth, fruit quality and yield of tomato led to a significant increase in plant height, fresh and dry weight (Suh et al. 2014) ${ }^{[23]}$. Application of Fulvic acid at different levels improves the quality parameters viz., Fruit antioxidant activity, total phenolic, carbohydrate, capsaicin and carotenoid contents in pepper.

Hence keeping the above points the present study was undertaken to standardize organic acid coating (Humic acid, Fulvic acid) for phosphatic fertilizer to improve the yield, quality as well as $\mathrm{P}$ use efficiency in Brinjal. 


\section{Materials and methods}

Field experiment was conducted during winter season (October - November) in the Farmer's field at Thondamuthur, Coimbatore, Tamil Nadu. The experimental site is geographically located at $10.99^{\circ} \mathrm{N}$ latitude and $76.83^{\circ} \mathrm{E}$ longitude at an altitude of $315 \mathrm{~m}$ above MSL. In the four rainfall seasons, Coimbatore received $859.50 \mathrm{~mm}$ rainfall which is $27.5 \%$ more than 50 year's average rainfall. The mean maximum and minimum temperatures were $32.5^{\circ} \mathrm{C}$ and $21^{\circ} \mathrm{C}$, respectively. The initial soil samples were collected from the experimental field and analyzed the initial physico chemical properties. The texture of the soil was sandy loam. The soil was low in available $\mathrm{N}$, high in available $\mathrm{P}$, and high in available $\mathrm{K}$.

The field experiment was laid out in Randomized Block Design (RBD) and consisted of ten treatments and replicated thrice. The treatments comprised of $\mathrm{T}_{1} \mathrm{NK}+\mathrm{P}$ as uncoated DAP, $\mathrm{T}_{2}: \mathrm{NK}+\mathrm{P}$ as FA coated $\mathrm{DAP}(5 \%), \mathrm{T}_{3}: \mathrm{NK}+\mathrm{P}$ as FA coated DAP (10\%), $\mathrm{T}_{4}: \mathrm{NK}+\mathrm{P}$ as FA coated DAP (15\%), $\mathrm{T}_{5}$ : $\mathrm{NK}+\mathrm{P}$ as FA coated DAP $(20 \%), \mathrm{T}_{6} \mathrm{NK}+\mathrm{P}$ as HA coated DAP $(5 \%), \mathrm{T}_{7}: \mathrm{NK}+\mathrm{P}$ as HA coated DAP $(10 \%), \mathrm{T}_{8}: \mathrm{NK}+\mathrm{P}$ as HA coated DAP $(15 \%), \mathrm{T}_{9}: \mathrm{NK}+\mathrm{P}$ as HA coated DAP (20\%), $\mathrm{T}_{10}$ : control. Urea and Muriate of potash (MOP) were used as the Nitrogen and potassium source respectively.

The coating of fertilizers was done using oil (vegetable oil). Subsequently mix the fertilizer and limited amount of oil with Humic acid and Fulvic acid separately by physical mixing. Then the fertilizers were dried in hot water bath for several hours until the moisture was removed completely. The dried material was used for the experiment. The Brinjal (CO2) seedlings were raised in the nursery for transplanting. Thoroughly the main field was ploughed and ridges and furrows were formed at a spacing of $60 \mathrm{~cm}$. The furrows were irrigated and 25-30 days old seedlings were transplanted at 60 $\mathrm{cm}$ apart on the ridges. The plots received normal cultural practices such as weeding, irrigation and plant protection and were preformed from time to time. All the cultural operations were carried out based on Crop Production Guide (CPG) Government of Tamilnadu. The growth and yield parameters were recorded.

Nitrogen and Potassium was applied in the form of Urea and MOP as per the fertilization schedule for Brinjal. Phosphorus was applied in the form of HA and FA coated DAP. Recommended dose of fertilizer for Brinjal (As per STCR recommendation) is $127: 37: 100 \mathrm{~kg}$ NPK ha-1. The fertilizer was applied as per the fertilization schedule at different growth stages. The crop was kept weed free with four hand weeding's. Irrigations were given as and when required. Better crop growth was ensured with the help of timely plant protection sprays which were followed by recommended cultural operations whenever required.

The total yield from each of the treatment plots were calculated and expressed in $\mathrm{kg}$. The total fruit yield was calculated by converting the per plot fruit yield on hectare basis and expressed in $\mathrm{t} \mathrm{ha}^{-1}$. Five plants in each plot other than guard row were randomly selected and tagged for recording observations on growth and yield parameters. Observations like number of fruits per plant, fruit length girth, fruit weight, and yield per plot were recorded. From the yield, gross returns can be calculated and this can be used for the calculation of benefit cost ratio. The soil samples were analysed for available $\mathrm{P}$ at different stages of Brinjal by using Olsen's extractant (Olsen et al., 1954) ${ }^{[18]}$.

The quality parameters were tested in laboratory. For the estimation of anthocyanin $10 \mathrm{~g}$ fruit sample was separated and samples were extracted with $10 \mathrm{~mL}$ of ethanolic $\mathrm{HCl}$. Extract was filtered and used for estimation. The absorbance of extracts clarified by filtration was measured at $535 \mathrm{~nm}$. Results were expressed as mg cynidin-3-glucoside equivalent per 100 $\mathrm{g}$ of FW.

Ascorbic acid content was determined by titration with an oxidizing agent namely indophenol dye. $10 \mathrm{~g}$ of fresh fruit taken in pestle and mortar blended with $4 \%$ oxalic acid. Pipette out the $10 \mathrm{~mL}$ of this solution into a $250 \mathrm{~mL}$ conical flask and titrate against standard indophenol dye till a permanent pink color is obtained. (Miller, 1998) ${ }^{[17]}$.

The titrable acidity in the fruit sample is estimated by macerating the fruit sample and add $20-30 \mathrm{~mL}$ of water and few drops of phenolphthalein indicator then titrate against $0.1 \mathrm{~N} \mathrm{NaOH}$. Endpoint is the appearance of pink colour. (Horwitz, 1975) ${ }^{[11]}$.

The data on the various characters recorded were statistically analysed under randomized block design as suggested by Gomez and Gomez (2010). Wherever the treatment differences were found to be significant (F-test), critical differences were worked out at five per cent probability level $(\mathrm{P}=0.05)$ and the treatment differences that were found not to be significant was denoted NS (Non-significant) in the respective tables.

\section{Results and discussions}

Effect of organic acid (HA, FA) coated Di ammonium phosphate on yield and soil available $\mathrm{P}$ are summarized in Table 1, Table 2 respectively.

\section{Yield attributes}

The maximum number of fruits per plant was observed in $\mathrm{T} 9$ $(\mathrm{NK}+\mathrm{P}$ as HA coated DAP $(20 \%)$ with values of 48 . This was followed by T8 (NK + P as HA coated DAP (15\%) which recorded 45.1. and then T3 $(\mathrm{NK}+\mathrm{P}$ as FA coated DAP $(10 \%)$ attain a value of 44.5. Similar findings were reported by Arancon et al. (2006) ${ }^{[4]}$, who explained peppers treated with humic acids extracted from organic source produced significantly more fruits and flowers. Shafeek (2016) ${ }^{[22]}$ studied in cucumber, indicated that the application of Humic acid increases the number of fruits per plant and also there is an increment in N\%, Protein\% and TSS\%. Farahi et al. (2013) [9] explained about the improvement of fruit number in strawberry.

The fruit length showed some differences between treatments. The minimum fruit length was observed in control $\left(\mathrm{T}_{10}\right)$ which recorded $7.6 \mathrm{~cm}$ and the maximum fruit length was noted in $\mathrm{T}_{9}(20 \%$ HA Coated DAP) which recorded $8.3 \mathrm{~cm}$. This was followed by $\mathrm{T}_{6}\left(5 \%\right.$ HA Coated DAP) and $\mathrm{T}_{4}(15 \%$ FA coated DAP) which attain a value of $8.1 \mathrm{~cm}$. The results are in line with the reports of Azarpour et al. (2012) ${ }^{[5]}$ who explained that foliar application of HA treatments positively affect that fruit length and width, fruit number per plant in brinjal. Manas et al., (2014) ${ }^{[16]}$ explained that the maximum fruit length registered in pepper plants which received the foliar application of $\mathrm{HA}+\mathrm{Zn}+\mathrm{B}$

The results of the current study shows that maximum fruit girth was observed in $\mathrm{T} 9$ which recorded $17.2 \mathrm{~cm}$ this was followed by $\mathrm{T}_{8}(16.4 \mathrm{~cm})$ then $\mathrm{T} 5(20 \% \mathrm{FA}$ coated DAP). which recorded $16.3 \mathrm{~cm}$. Similar findings were given by Azarpour et al. (2012) ${ }^{[5]}$. Also, Yildrim, who explained that foliar and soil HA treatments improves the fruit diameter in tomato. Salman (2005) ${ }^{[21]}$ given that application of Humic acid increased the fruit diameter in watermelon. 
According to the data observed on fruit weight showed that $\mathrm{T}_{9}$ has got the maximum fruit weight followed by $\mathrm{T}_{8}$ and $\mathrm{T}_{5}$. This recorded $83.4 \mathrm{~g}, 76.8 \mathrm{~g}$ and $74.9 \mathrm{~g}$ respectively. The fruit weight was minimum $(59.9 \mathrm{~g})$ in the treatment control followed by $\mathrm{T}_{1}$ (uncoated DAP). El-Nemr (2015) ${ }^{[21]}$ studied the responses of eggplants with different foliar concentrations of some bio-stimulators which show that humic acid application has improved the fruit weight. Similar results were reported by Azarpour et al. (2012) ${ }^{[5]}$. Karakurt et al. (2009) [4] observed that the fruit weight of pepper was enhanced by the application of Humic acid. Humic acid improve the fruit weight by activating hormones like auxin and cytokinin (Huang, Yuan et al. 2009) ${ }^{[12]}$. Humic acid holds many elements which increase the availability of trace minerals and consequently affected plant growth and yield (Hartwigson and Evans, 2000) [10]. El-kenawy (2017) [6] observed that fulvic acid application in Thompson seedless grape increased the yield.

Among the 10 treatments $\mathrm{T}_{9}(20 \%$ HA coated DAP) surpassed other treatments by achieving the highest fruit yield per hectare $\left(31.18 \mathrm{t} \mathrm{ha}^{-1}\right)$ and which was superior to the next best treatment $\mathrm{T}_{8}(15 \%$ HA coated DAP) which recorded $30.43 \mathrm{t} \mathrm{ha}^{-1}$. The lowest fruit yield was observed in $\mathrm{T}_{10}$ (control) which reported the value $17.92 \mathrm{t} \mathrm{ha}^{-1}$. Compared to uncoated DAP, HA coating at $20 \%$ in DAP recorded $14.88 \%$ increase in yield followed by HA coating at $15 \%$ in DAP (12.12\% increase in yield). Similar findings were observed by Paramasivan et al. (2015) ${ }^{[20]}$ in Brinjal, who studied the influence of Humic acid yield of Brinjal and results found that highest fruit yield and total dry matter production were recorded in $75 \%$ RDF of NPK with $10 \mathrm{~kg}$ of Humic acid applied as soil application and $0.2 \%$ foliar application.

The results revealed that the organic acid coated DAP fertilizer has brought variations in yield attributes of Brinjal. The different concentrations of Humic acid and Fulvic acid helps in growth and yield of plant. 20\% Humic acid coated DAP fertilizers followed by $15 \%$ HA coated DAP showed the highest yield ie.14.88\% and $12.12 \%$ increase in yield, respectively over uncoated DAP.

Table 1: Effect of Organic acid coated DAP fertilizer on yield attributes of brinjal (Solanum melongena L.)

\begin{tabular}{|c|c|c|c|c|c|c|}
\hline T.no & Treatments & $\begin{array}{l}\text { Average fruit weight } \\
(\mathrm{g})\end{array}$ & $\begin{array}{c}\text { Number of fruits per plant } \\
\text { (Nos.) }\end{array}$ & $\begin{array}{c}\begin{array}{c}\text { Fruit length } \\
(\mathrm{cm})\end{array} \\
\end{array}$ & $\begin{array}{l}\text { Fruit girth } \\
(\mathrm{cm})\end{array}$ & \begin{tabular}{|c|}
$\begin{array}{c}\text { Fruit Yield } \\
\left(\mathrm{t} \mathrm{ha}^{-1}\right)\end{array}$ \\
\end{tabular} \\
\hline $\mathrm{T}_{1}$ & $\mathrm{NK}+\mathrm{P}$ as Uncoated DAP & 65.6 & 37.7 & 8.1 & 614.6 & 27.14 \\
\hline $\mathrm{T}_{2}$ & $\mathrm{NK}+\mathrm{P}$ as FA coated DAP (5\%) & 69.5 & 39.0 & 7.9 & 14.9 & 28.35 \\
\hline $\mathrm{T}_{3}$ & $\mathrm{NK}+\mathrm{P}$ as FA coated DAP $(10 \%)$ & 72.6 & 44.5 & 8.0 & 15.3 & 28.12 \\
\hline $\mathrm{T}_{4}$ & $\mathrm{NK}+\mathrm{P}$ as FA coated DAP $(15 \%)$ & 74.6 & 42.0 & 8.1 & 15.6 & 28.74 \\
\hline $\mathrm{T}_{5}$ & $\mathrm{NK}+\mathrm{P}$ as FA coated DAP $(20 \%)$ & $74 . .9$ & 43.6 & 7.9 & 16.3 & 29.66 \\
\hline $\mathrm{T}_{6}$ & $\mathrm{NK}+\mathrm{P}$ as HA coated DAP $(5 \%)$ & 66.3 & 37.8 & 8.1 & 15.5 & 26.69 \\
\hline $\mathrm{T}_{7}$ & $\mathrm{NK}+\mathrm{P}$ as HA coated DAP $(10 \%)$ & 74.6 & 41.8 & 7.8 & 16.2 & 29.49 \\
\hline $\mathrm{T}_{8}$ & $\mathrm{NK}+\mathrm{P}$ as HA coated DAP $(15 \%)$ & 76.8 & 45.1 & 8.0 & 16.4 & 30.43 \\
\hline $\mathrm{T}_{9}$ & $\mathrm{NK}+\mathrm{P}$ as HA coated DAP $(20 \%)$ & 83.4 & 48.0 & 8.3 & 17.2 & 31.18 \\
\hline \multirow[t]{3}{*}{$\mathrm{T}_{10}$} & Control & 59.9 & 29.5 & 7.6 & 13.5 & 17.92 \\
\hline & SEd & 1.22 & 0.94 & 0.191 & 0.350 & 0.465 \\
\hline & $\mathrm{CD}(\mathrm{P}=0.05)$ & 2.56 & 1.98 & NS & 0.736 & 0.976 \\
\hline
\end{tabular}

All treatments received 127:37:100 kg N:P $\mathrm{P}_{2} \mathrm{O}_{5}: \mathrm{K}_{2} \mathrm{O} \mathrm{ha}^{-1}$ as per soil test based recommendation

$\mathrm{N}$ as Urea, $\mathrm{P}$ as Coated DAP and $\mathrm{K}$ as MOP

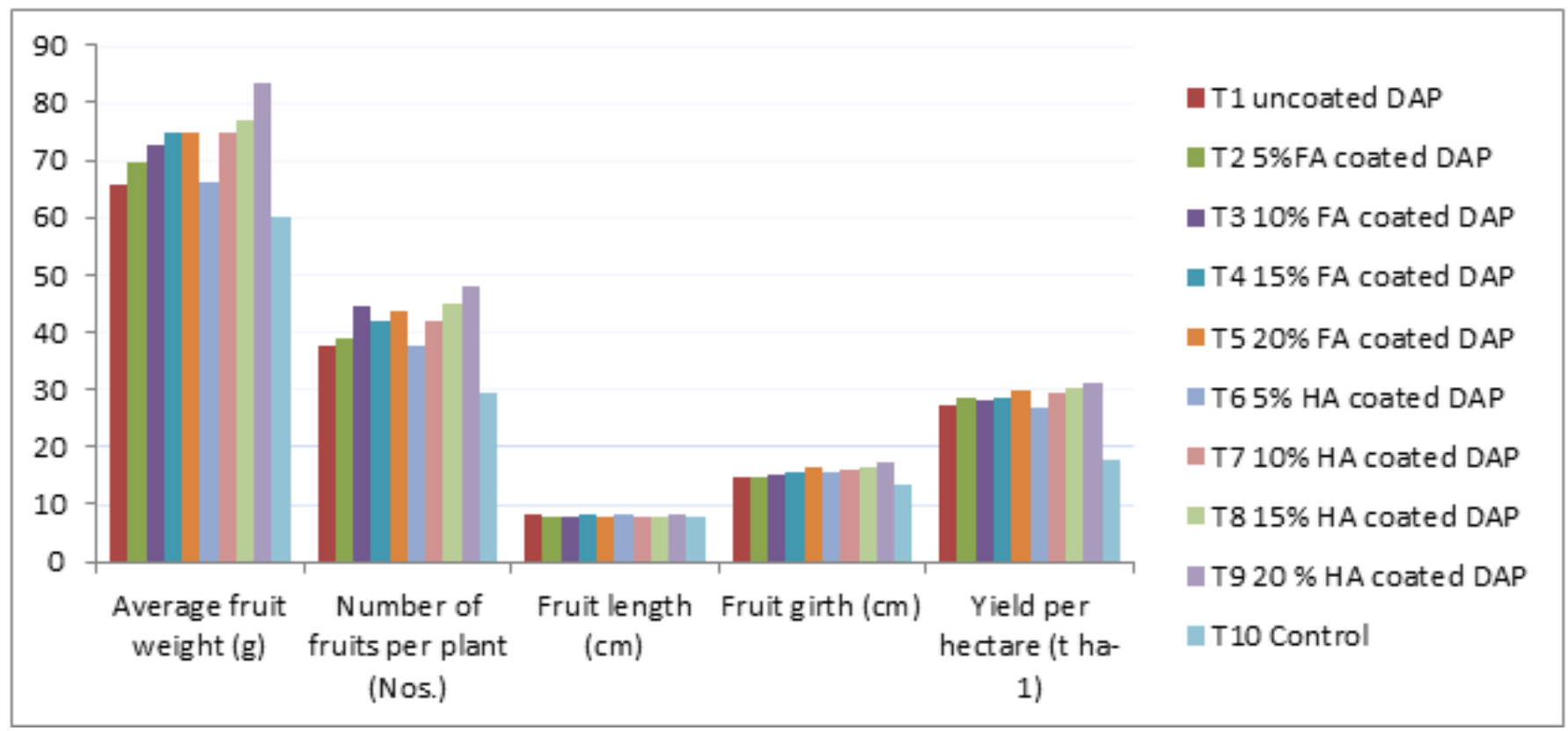

Fig 1: Deviation of yield attributes with respect to treatment 


\section{Benefit cost ratio}

Table 2: Deviation of Benefit cost ratio with respect to treatments

\begin{tabular}{|c|c|c|c|c|}
\hline Sl.no & Treatment & Gross returns (lakh/ha) & Net Returns (lakh/ha) & BC Ratio \\
\hline 1 & NK+ P as Uncoated DAP & 6.11 & 4.7 & 4.44 \\
\hline 2 & NK+ P as FA coated DAP (5\%) & 6.39 & 4.99 & 4.61 \\
\hline 3 & NK+ P as FA coated DAP (10\%) & 6.33 & 4.94 & 4.56 \\
\hline 4 & NK+ P as FA coated DAP (15\%) & 6.46 & 5.07 & 4.64 \\
\hline 5 & NK+ P as FA coated DAP (20\%) & 6.67 & 5.27 & 4.77 \\
\hline 6 & NK+ P as HA coated DAP (5\%) & 6.01 & 4.62 & 4.33 \\
\hline 7 & NK+ P as HA coated DAP (10\%) & 6.63 & 5.23 & 4.74 \\
\hline 8 & NK+ P as HA coated DAP (15\%) & 6.81 & 5.39 & 4.82 \\
\hline 9 & NK+ P as HA coated DAP (20\%) & 7.01 & 5.59 & 4.93 \\
\hline 10 & Control & 6.24 & 4.94 & 4.77 \\
\hline
\end{tabular}

All treatments received 127:37:100 kg N:P $\mathrm{P}_{2} \mathrm{O}_{5}: \mathrm{K}_{2} \mathrm{O} \mathrm{ha}^{-1}$ as per soil test based recommendation

$\mathrm{N}$ as Urea, $\mathrm{P}$ as Coated DAP and $\mathrm{K}$ as MOP

The application of $20 \%$ HA coated DAP $\left(\mathrm{T}_{9}\right)$ fetched significantly higher net returns and benefit cost ratio (4.93) over the rest of treatments (Table 2). The second best treatment was $15 \%$ HA coated DAP which recorded a benefit cost ratio of 4.82 , this might be due to achieved higher productivity as well as lower cost of cultivation leading to higher economic returns in Brinjal. These results are in close conformity with the findings of Paramasivan et al. (2015) [20] and Abd et al (2005) ${ }^{[1]}$.

\section{Soil available phosphorus}

Coated phosphatic fertilizers regulate release of phosphorus in the soil. Also net fertilizer P efficiency, dry matter production, $\mathrm{P}$ uptake, and net fertilizer release efficiency were better in coated fertilizers. Lubkowski (2014) ${ }^{[15]}$ studied the use of biodegradable chitosan to coated fertilizer granules with an inert, impermeable layer in facilitated controlled release properties. As the layer thickness increases the degree of release decreases. Teixeira et al., (2016) ${ }^{[24]}$ observed that use of organic acid coating facilitated the slow release of phosphorus fertilizers and improves the $\mathrm{P}$ availability in maize crop. Coating with humic acids reduced the water solubility of the $\mathrm{P}$ fertilizers, increased the agronomic efficiency (AE) of $\mathrm{P}$ led to higher values of apparent $\mathrm{P}$ recovery by maize. Erro et al., (2016) ${ }^{[8]}$ studied about improvement of phosphorus use efficiency using humic substances. And it was concluded that humic substances can improve the phosphorus efficiency.

The initial soil available $\mathrm{P}$ of the experimental field was high. The available $\mathrm{P}$ in soil showed significant variation in different growth stages of Brinjal. $\mathrm{T}_{9}(20 \%$ HA coated DAP) showed highest soil available P compared to other treatments (39.82 kg/ha) this was followed by $\mathrm{T}_{8}(15 \%$ HA coated DAP) which was on par with $\mathrm{T}_{5}(20 \%$ FA coated DAP). The least available in soil was obtained in the treatment T10 (control) followed by $\mathrm{T}_{1}$ (uncoated DAP). The results were confirmed with the findings of $\mathrm{Wu}$ and Liu (2008) ${ }^{[26]}$ and Teixeira et al., $(2016)^{[24]}$

Table 3: Effect of Organic acid coated DAP fertilizer on soil available phosphorus

\begin{tabular}{|c|c|c|c|c|c|}
\hline Tr.no & Treatments & Vegetative stage & Flowering stage & Fruiting stage & Harvest stage \\
\hline $\mathrm{T}_{1}$ & NK+ P as Uncoated DAP & 41.2 & 37.7 & 33.2 & 28.41 \\
\hline $\mathrm{T}_{2}$ & NK+ P as FA coated DAP (5\%) & 45.6 & 40.64 & 34.92 & 31.11 \\
\hline $\mathrm{T}_{3}$ & NK+ P as FA coated DAP (10\%) & 46.2 & 41.68 & 35.88 & 33.27 \\
\hline $\mathrm{T}_{4}$ & NK+ P as FA coated DAP (15\%) & 48.1 & 43.33 & 38.11 & 35.22 \\
\hline $\mathrm{T}_{5}$ & NK+ P as FA coated DAP (20\%) & 49.8 & 45.4 & 40.2 & 37.11 \\
\hline $\mathrm{T}_{6}$ & NK+ P as HA coated DAP (5\%) & 43.60 & 39.21 & 35.36 & 32.22 \\
\hline $\mathrm{T}_{7}$ & NK+P as HA coated DAP (10\%) & 45.3 & 41.33 & 38.11 & 35.89 \\
\hline $\mathrm{T}_{8}$ & NK+P as HA coated DAP (15\%) & 48.2 & 43.22 & 40.2 & 37.32 \\
\hline $\mathrm{T}_{9}$ & NK+P as HA coated DAP (20\%) & 51.69 & 45.23 & 42.66 & 39.82 \\
\hline $\mathrm{T}_{10}$ & Control & 27.98 & 21.22 & 19.12 & 18.58 \\
\hline & SEd & 2.11 & 0.96 & 0.80 & 0.44 \\
\hline & CD (P = 0.05) & 2.01 & 1.68 & 0.93 \\
\hline
\end{tabular}

All treatments received 127:37:100 kg N: $\mathrm{P}_{2} \mathrm{O}_{5}: \mathrm{K}_{2} \mathrm{O}$ ha $^{-1}$ as per soil test based recommendation

$\mathrm{N}$ as Urea, $\mathrm{P}$ as Coated DAP and $\mathrm{K}$ as MOP

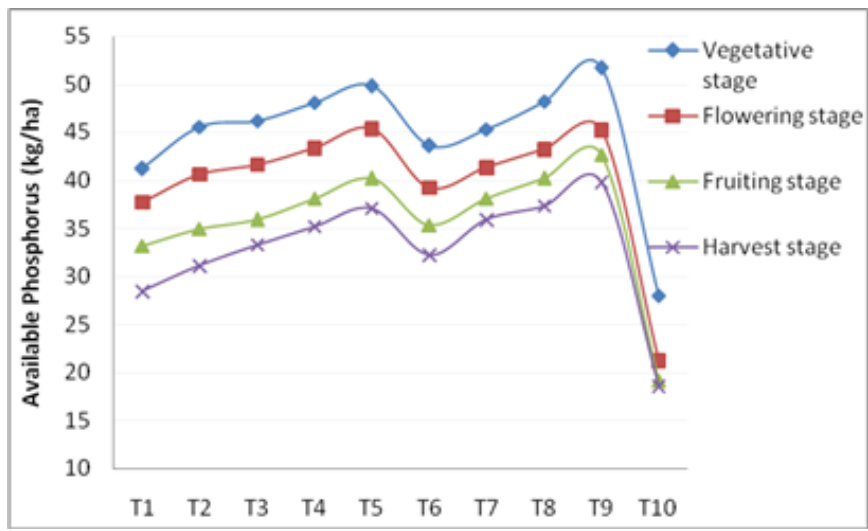

Fig 2: Available phosphorus at different stages of growth of brinjal with respect to treatments $\sim 50 \sim$ 


\section{Quality parameters}

Anthocyanin content (mg $\left.100 \mathrm{~g}^{-1}\right)$

The results showed that there is no significant difference in the anthocyanin content with respect to treatments. Among the treatments highest anthocyanin content was reported in in $\mathrm{T}_{9}\left(11.56 \mathrm{mg} 100 \mathrm{~g}^{-1}\right)$ which was followed by $\mathrm{T}_{8}(11.48 \mathrm{mg}$ $100 \mathrm{~g}^{-1}$. Similar results were given by Alcija et al. (2019).

\section{Ascorbic acid content (mg $\left.100 \mathrm{~g}^{-1}\right)$}

There is slight increase in ascorbic content of Brinjal with respect to treatments. The highest ascorbic content was obtained in $\mathrm{T}_{9}$ which recorded a value of $16.68 \mathrm{mg} 100 \mathrm{~g}^{-1}$ followed by $\mathrm{T}_{8}\left(16.65 \mathrm{mg} 100 \mathrm{~g}^{-1}\right)$. Similar results were reported by in tomato.

\section{Titrable acidity $(\%)$}

There is no significant difference between treatments. Titrable acidity value is a generically made character of fruit which might not be vary with the different concentrations of organic acid coated phosphate fertilizers. The values of Titrable acidity ranged from 0.26 to $0.31 \%$. Similar results were reported by in tomato.

Table 4: Effect of HA\&FA coated phosphatic fertilizers on quality parameters in Brinjal variety $\mathrm{CO} 2$

\begin{tabular}{|c|c|c|c|c|}
\hline Tr. No. & Treatments & Anthocyanin content $\left(\mathrm{mg} 100 \mathrm{~g}^{-1}\right)$ & Ascorbic acid content $\left({\left.\mathrm{mg} 100 \mathrm{~g}^{-1}\right)}\right)$ & Titrable acidity (\%) \\
\hline $\mathrm{T}_{1}$ & $\mathrm{NK}+\mathrm{P}$ as Uncoated DAP & 11.43 & 16.34 & 0.29 \\
\hline $\mathrm{T}_{2}$ & $\mathrm{NK}+\mathrm{P}$ as FA coated DAP $(5 \%)$ & 11.21 & 16.42 & 0.28 \\
\hline $\mathrm{T}_{3}$ & $\mathrm{NK}+\mathrm{P}$ as FA coated DAP $(10 \%)$ & 11.32 & 16.36 & 0.29 \\
\hline $\mathrm{T}_{4}$ & $\mathrm{NK}+\mathrm{P}$ as FA coated DAP (15\%) & 11.28 & 16.41 & 0.31 \\
\hline $\mathrm{T}_{5}$ & $\mathrm{NK}+\mathrm{P}$ as FA coated DAP (20\%) & 11.35 & 16.48 & 0.28 \\
\hline $\mathrm{T}_{6}$ & $\mathrm{NK}+\mathrm{P}$ as HA coated DAP (5\%) & 11.43 & 16.47 & 0.27 \\
\hline $\mathrm{T}_{7}$ & $\mathrm{NK}+\mathrm{P}$ as HA coated DAP $(10 \%)$ & 11.31 & 16.52 & 0.29 \\
\hline $\mathrm{T}_{8}$ & $\mathrm{NK}+\mathrm{P}$ as HA coated DAP $(15 \%)$ & 11.48 & 16.65 & 0.30 \\
\hline $\mathrm{T}_{9}$ & $\mathrm{NK}+\mathrm{P}$ as HA coated DAP $(20 \%)$ & 11.56 & 16.68 & 0.28 \\
\hline $\mathrm{T}_{10}$ & Control & 11.1 & 16.32 & 0.26 \\
\hline & SEd & 0.27 & 0.011 & 0.012 \\
\hline & $\mathrm{CD}(\mathrm{P}=0.05)$ & $\mathrm{NS}$ & 0.0227 & $\mathrm{NS}$ \\
\hline
\end{tabular}

All treatments received 127:37:100 kg N: $\mathrm{P}_{2} \mathrm{O}_{5}: \mathrm{K}_{2} \mathrm{O}$ ha ${ }^{-1}$ as per soil test based recommendation

$\mathrm{N}$ as Urea, $\mathrm{P}$ as Coated DAP and $\mathrm{K}$ as MOP

\section{Conclusion}

Over all conclusions drawn from the field experiment is that slowing the release of fertilizer $\mathrm{P}$ into the soil by organic acid coated phosphatic fertilizers can markedly increase yield and soil available phosphorus. Among the coated fertilizers Humic acid coated DAP fertilizer excelled in yield as well as soil available $\mathrm{P}$ status. Also, the application of $20 \%$ HA coatd DAP fetched significantly higher net returns and benefit cost ratio. Hence, the present study revealed that organic acid coated phosphate fertilizer can be safely used within the applied concentrations with a positive effect on yield parameters like number fruits per plant, fruit length, fruit girth, fruit weight, yield per plot and yield per hectare, improvement in soil available $\mathrm{P}$ status, ascorbic acid content and also in economic returns. Application of $20 \%$ HA coated DAP can be recommended for the better fruit yield of brinjal, Benefit cost ratio, and available soil $P$ status.

\section{References}

1. Abd FSEA, Shafeek MR, Ahmed AA, Shaheen AM. Response of growth and yield of onion plants to potassium fertilizer and humic acid $J$ Agric Sci. 2005; 30:441-452.

2. Alicja POHL, Grabowska A, Kalisz A, Sekara A. The eggplant yield and fruit composition as affected by genetic factor and biostimulant application. Notulae Botanicae Horti Agrobotanici Cluj-Napoca. 2019; 47(3):929-938

3. Aminifard MH, Aroiee H, Nemati H, Azizi M, Jaafar HZ. Fulvic acid affects pepper antioxidant activity and fruit quality, African Journal of biotechnology. 2012; 11(68):13179-13185.

4. Arancon NQ, Edwards CA, Lee S, Byrne R. Effects of humic acids from vermicompost son plant growth, European Journal of soil biology. 2006; 42:65-69.

5. Azarpour E, Motamed MK, Moraditochaee M, Bozorgi HR. Effects of bio mineral nitrogen fertilizer management, under humic acid foliar spraying on fruit yield and several traits of eggplant (Solanum melongena L), African Journal of agricultural research. 2012; 7(7):1104-1109.

6. El-kenawy MA. Effect of chitosan, salicylic acid and fulvic acid on vegetative growth, yield and fruit quality of Thompson seedless grapevines, Egyptian journal of horticulture. 2017; 44(1):45-59.

7. El-Nemr MA, El-Bassiony AM, Tantawy AS, Fawzy ZF. Responses of eggplant (Solanum melongena var. esculenta L) plants to different foliar concentrations of some Bio-Stimulators, Middle East J Agric Res. 2015; 4(4):860-866.

8. Erro J, Urrutia O, Baigorri R, Fuentes M, Zamarreño AM, Garcia-Mina JM. Incorporation of humic-derived active molecules into compound NPK granulated fertilizers: main technical difficulties and potential solutions, Chemical and biological technologies in agriculture. 2016; 3(1):18.

9. Farahi MH, Aboutalebi A Eshghi S, Dastyaran M, Yosefi F. Foliar application of Humic acid on quantitative and qualitative characteristics of' Aromas' strawberry in soilless culture, agricultural communications. 2013; 1(1):13-16.

10. Hartwigsen J.A, Evans M.R. Humic acid seed and substrate treatments promote seedling root development Hort Science. 2000; 35(7):1231-1233

11. Horwitz W. Official methods of analysis, Washington, DC: Association of official analytical chemists, 1975, 222.

12. Huang Y, Bie Z, Liu Z, Zhen A, Wang W. Protective role of proline against salt stress is partially related to the improvement of water status and peroxidase enzyme activity in cucumber, soil science and plant nutrition. 2009; 55(5):698-704.

13. Iqbal S, Mastorakis N. Effect of various growth mediums on the germination and growth of Jatrophacurcas, 
In proceedings of the 2 nd International conference of geodesy \& Geomatics engineering (GENG'14), Brasov, Romania. 2014; 26(28):147-156.

14. Karakurt Y, Unlu H, Unlu H, Padem H. The influence of foliar and soil fertilization of humic acid on yield and quality of pepper Acta Agriculturae Scandinavica section B-Soil and plant science. 2009; 59(3):233-237

15. Lubkowski K. Coating fertilizer granules with biodegradable materials for controlled fertilizer release, Environmental engineering \& management Journal (EEMJ). 2014; 13:10.

16. Manas D, Bandopadhyay PK, Chakravarty A, Pal S, Bhattacharya A. Effect of foliar application of humic acid, zinc and boron on biochemical changes related to productivity of pungent pepper (Capsicum annuиm L) plant sci. 2014; 8(6):320-335.

17. Miller DD. Food chemistry: A laboratory manual New York, NY, USA Wiley, 1998.

18. Olsen SR. Estimation of available phosphorus in soils by extraction with sodium bicarbonate (No) US department of agriculture, 1954, 939.

19. Pauly DG, Malhi SS, Nyborg M. Controlled-release P fertilizer concept evaluation using growth and $\mathrm{P}$ uptake of barley from three soils in greenhouse Canadian Journal of soil science. 2002; 82(2):201-210.

20. Paramasivan M, Arun Kumar V, Prabhu T. Effect of humic acid and inorganic fertilizers on productivity, profitability, nutrient uptake and soil fertility in brinjal (Solanum melongena L.) var. KKM1 in Alfisol of Tamil Nadu, Asian journal of soil science. 2015; 10(2):185-190.

21. Salman SR, Abou-Hussein SD, Abdel-Mawgoud AMR, El-Nemr MA. Fruit yield and quality of watermelon as affected by hybrids and humic acid application, Journal of applied sciences research. 2005; 1(1):51-58.

22. Shafeek MR, Helmy YI, Omar NM. Effect of spraying or ground drench from humic acid on growth, total output and fruits nutritional values of cucumber (Cucumis sativus L.) grown under plastic house conditions Int $\mathbf{J}$ Pharma tech res. 2016; 9(12):52-57.

23. Suh HY, Yoo KS, Suh SG. Effect of foliar application of fulvic acid on plant growth and fruit quality of tomato (Lycopersicon esculentum L.) Horticulture, environment, and biotechnology. 2014; 55(6):455-461.

24. Teixeira RDS, Ribeiro da Silva I, Nogueira de Sousa R, Márcio Mattiello E, Barros Soares EM. Organic acid coated-slow-release phosphorus fertilizers improve $\mathrm{P}$ availability and maize growth in a tropical soil, Journal of soil science and plant nutrition. 2016; 16(4):1097-1112.

25. Ugur A, Demİrtas B, Caglar S, Zambİ O, Turkmen M. Effect of humic acid application on yield and quality in green vegetables, In Proceedings of the 24th International scientific-expert-conference of agriculture and food industry, Sarajevo, Bosnia and Herzegovina, Faculty of agriculture and food sciences, University of Sarajevo. 2013; 25-28:381-385.

26. Wu L, Liu M. Preparation and properties of chitosancoated NPK compound fertilizer with controlled-release and water-retention carbohydrate polymers. 2008; 72(2):240-247.

27. Yildirim E. Foliar and soil fertilization of humic acid affect productivity and quality of tomato, Acta Agriculturae Scandinavica section B-soil and plant science. 2007; 57(2):182-186. 